\title{
Roles of bacterial community composition in biofilms as a mediator for larval settlement of three marine invertebrates
}

\author{
Stanley C. K. Lau, Vengatesen Thiyagarajan, Sam C. K. Cheung, Pei-Yuan Qian* \\ Department of Biology/Coastal Marine Laboratory, The Hong Kong University of Science and Technology, \\ Clear Water Bay, Kowloon, Hong Kong SAR, China
}

\begin{abstract}
This study investigated (1) the effects of salinity and temperature on the bacterial community composition of developing biofilms, and (2) the responses of marine invertebrate larvae (the polychaete Hydroides elegans and the barnacles Balanus amphitrite and B. trigonus) to these biofilms during settlement (i.e. attachment to a surface and metamorphosis into juveniles). Biofilms developed in a $3 \times 3$ array of salinity and temperature treatments resulted in different bacterial community compositions (revealed by DGGE and T-RFLP), bacterial densities and total biomasses. Larval settlement of $B$. amphitrite and $B$. trigonus was induced by biofilms developed at high temperatures $\left(23\right.$ and $\left.30^{\circ} \mathrm{C}\right)$, but was unaffected $(B$. amphitrite) or inhibited (B. trigonus) by those developed at a low temperature $\left(16^{\circ} \mathrm{C}\right)$. The settlement response of these barnacles did not correlate with the biomass or the bacterial density of the biofilms, but did coincide with the marked differences in bacterial community composition between the biofilms developed at different temperatures. In contrast, larval settlement of $H$. elegans differed slightly among biofilms developed in different salinities, but not among those developed at different temperatures. This settlement response was moderately correlated with bacterial density but had no apparent relationship with bacterial community composition of the biofilms. Our results implied that the community composition and cell density of bacteria in biofilms, which can vary with local environmental conditions, may allow larvae of the 2 barnacles and $H$. elegans, respectively, to distinguish between habitats with different environmental conditions.
\end{abstract}

KEY WORDS: Bacterial community · Barnacle · Biofilm · DGGE - Larval settlement · Polychaete · T-RFLP

Resale or republication not permitted without written consent of the publisher

\section{INTRODUCTION}

Many sessile marine invertebrates have a pelagic larval stage specialized for dispersal and colonization of new habitats (Thorson 1950). After a period of development (from hours to weeks, depending on the species), larvae enter a competent stage wherein they have developed the ability to settle (i.e. attach to substrata and metamorphose into juveniles). Competent larvae can detect diverse arrays of environmental stimuli to determine whether an encountered habitat is suitable for settlement (Morse 1991). An important source of environmental stimuli for many marine invertebrates are biofilms - complex agglomerates of bacteria, diatoms, protozoa and fungi existing on virtually all submerged substrata (Wieczorek \& Todd 1998).

Biofilms were once thought to simply act as a sticky layer that 'entraps' and 'forces' larvae to settle (Zobell \& Allen 1935). In fact, larvae can have finely tuned responses to biofilms; they are able to distinguish between biofilms developed in different geographic locations and settle on those that are relevant to their adult habitats (Bonar et al. 1986, Le Tourneux \& 
Bourget 1988, Pearce \& Scheibling 1991, Keough \& Raimondi 1996). This subtle response is believed to be mediated by the structural and/or physiological attributes of biofilms, which may vary spatially and temporally according to the biotic (e.g. availability and physiology of colonizing species, competition and cooperation among species, and grazing pressure) and abiotic factors (e.g. latitude, depth, illumination, exposure time, season, water chemistry, nutrient supply, flow shear and substratum characteristics) of the local environment (Wieczorek \& Todd 1998).

Despite decades of study, the bioactive components of biofilms that mediate larval settlement are still largely unknown. Many investigations have nevertheless highlighted the bacterial component of biofilms as a major mediator for larval settlement of many invertebrates (Holmström et al. 1992, Harder et al. 2002, Qian et al. 2003). In laboratory assays, monospecies films of bacteria can influence larval settlement in a variety of ways (from inhibition to neutral to induction), depending on the species of bacteria and larvae of concern. The specificity of larval response to different species of bacteria as well as the sensitivity of biofilm bacterial community composition to environmental factors have led to the hypothesis that larvae might be able to distinguish between habitats by responding differentially to bacteria that prevail in particular environments (Strathmann et al. 1981, Thomason et al. 1998, Miron et al. 1999, Olivier et al. 2000).

The development and verification of this hypothesis have relied mostly on culture-dependent techniques and morphological characterization to describe bacterial community composition in the biofilms (Maki et al. 1988, Holmström et al. 1992, Avelin et al. 1993, O'Connor \& Richardson 1998). However, these approaches generally suffer from the fact that $<1 \%$ of bacterial species in the marine environment are culturable and that bacteria are largely indistinguishable by morphological characteristics (Eilers et al. 2000). Therefore, investigations based on conventional techniques are incomplete and often bear a strong speculative element. The objective of this study was to use a culture-independent approach (i.e. DNA fingerprinting techniques) to investigate the hypothesized role of bacterial community composition in biofilms as a signpost for larvae to recognize desirable habitats. Specifically, we tested the effects of 2 environmental parameters (salinity and temperature) on the bacterial community composition of developing biofilms (as characterized by 2 DNA fingerprinting techniques). We then investigated the effects of these biofilms on larval settlement of 3 marine invertebrates (the polychaete Hydroides elegans, and the barnacles Balanus amphitrite and B. trigonus) in laboratory assays.

\section{MATERIALS AND METHODS}

Biofilm development. Two batches of biofilms were developed in March and April 2003 on pre-sterile polystyrene dishes (base area ca. $20 \mathrm{~cm}^{2}$; Falcon \#1006) in a $3 \times 3$ array of salinity $(20,27,34 \%$ ) and temperature $\left(16,23,30^{\circ} \mathrm{C}\right)$ treatments. This array represented the range of salinities and temperatures normally encountered in Hong Kong waters throughout the year. We did not intend to investigate whether the biofilms developed in these treatments would allow larvae to distinguish between habitats of different salinity and/or temperature, but rather to use salinity and temperature as 'tools' to create biofilms of various bacterial communities and to use these biofilms to investigate whether larvae could distinguish between them.

To set up the treatments, seawater taken from the pier at the Hong Kong University of Science and Technology (HKUST) was diluted to the desired salinities $(20,27,34 \%$ o using autoclaved double-distilled water. Seawater at each salinity was transferred to 3 aquaria (10 l) each containing 24 dishes mounted vertically to the aquarium wall. The 3 replicate aquaria of each salinity were allocated to 16,23 , and $30^{\circ} \mathrm{C}$ treatments by placing the aquaria in temperature-controlled water baths. Biofilms were developed on the dishes over a $20 \mathrm{~d}$ incubation period on a 15:9 h light:dark cycle with aeration. The seawater in the aquaria was changed every $48 \mathrm{~h}$.

Enumeration of bacteria. Biofilms in 3 replicate dishes of each treatment were fixed with $4 \%$ formaldehyde in $0.22 \mathrm{~mm}$ filtered seawater (FSW). After staining with 4,6-diamidino-2-phenylindole, bacterial density was enumerated using an epifluorescence microscope at a magnification of 1000 in 10 haphazardly chosen fields of view on each biofilm. At least 1000 cells were counted for each biofilm.

Biofilm biomass measurement. Biofilms were scraped from 3 replicate dishes of each treatment using sterile glass coverslips, lysed by ultrasonic pulses (Branson Sonifier 450) and analyzed for total organic carbon (TOC) using high temperature catalytic oxidation at $680^{\circ} \mathrm{C}$ in a Shimadzu TOC- $\mathrm{V}_{\mathrm{CPH} / \mathrm{CPN}}$ analyzer (Shimadzu Corporation) according to the manufacturer's protocol.

DNA extraction. Biofilms scraped from 3 replicate dishes of each treatment using sterile glass coverslips were combined and then suspended in $0.8 \mathrm{ml}$ of lysis buffer (100 mM Tris- $\mathrm{HCl}, 100 \mathrm{mM}$ sodium EDTA, $100 \mathrm{mM}$ sodium phosphate, $1.5 \mathrm{M} \mathrm{NaCl}, 1 \%$ hexadecylmethylammonium bromide; $\mathrm{pH}=8.0$ ). Total DNA was extracted and purified according to Zhou et al. (1996).

Polymerase chain reaction (PCR). The 16S rRNA genes of bacteria in the DNA were PCR amplified 
using the primer pairs 968F-GC (5'-GAACGCGAAGAACCTTAC-3') and 1346R (5'-TAGCGATTCCGACTTCA-3') (Nübel et al. 1996) for DGGE, and 341F-HEX (5'-CCTACGGGAGGCAGCAG-3') and 907R (5'CCGTCAATTCCTTTRAGTTT-3') (Ishii et al. 2000) for T-RFLP analysis. The primers $968 \mathrm{~F}-\mathrm{GC}$ and 341F-HEX carry a 39-base GC-clamp (5'-CGCCCGGGGCGCGCCCCGGGCGGGGCGGGGGCACGGGGG-3') and a fluorescent label (HEX, hexachlorofluorescein) at their $5^{\prime}$ ends, respectively. PCR was performed in a total volume of $50 \mathrm{ml}$ containing $2 \mathrm{ml}$ of DNA template, $250 \mathrm{mM}$ of each deoxyribonucleotide triphosphate (dATP, dCTP, dGTP, dTTP; Pharmacia Biotechnology), $1 \mathrm{U}$ of AmpliTaq Gold ${ }^{\mathrm{TM}}$ DNA polymerase (Applied Biosystems) in 1 buffer, $1.5 \mathrm{mM} \mathrm{MgCl}{ }_{2}$ and $1 \mathrm{mM}$ of each primer. PCR was performed at $95^{\circ} \mathrm{C}$ for $10 \mathrm{~min} ; 25$ cycles of $95^{\circ} \mathrm{C}$ for $1 \mathrm{~min}, 56^{\circ} \mathrm{C}$ for $3 \mathrm{~min}, 72^{\circ} \mathrm{C}$ for $3 \mathrm{~min}$; and $72^{\circ} \mathrm{C}$ for $10 \mathrm{~min}$. The amount and size of amplified DNA was verified by electrophoresis in agarose.

Denaturing gradient gel electrophoresis (DGGE). DGGE of PCR products was performed in a DGGE1001 system (C.B.S. Scientific). The PCR products were resolved in a $1 \mathrm{~mm}$ thick vertical gel containing $8 \%(\mathrm{w} / \mathrm{v})$ polyacrylamide (37.5:1 acrylamide:bisacrylamide) and a linear gradient of 45 to $60 \%$ chemical denaturants, whereas $100 \%$ denaturants refers to $7 \mathrm{M}$ urea and $40 \%(\mathrm{v} / \mathrm{v})$ formamide. Electrophoresis $(100 \mathrm{~V}$ for $17 \mathrm{~h}$ ) was performed in 1 TAE buffer maintained at $60^{\circ} \mathrm{C}$. After that, DNA was visualized using silver stain according to Bassam et al. (1991).

Terminal restriction fragment length polymorphism (T-RFLP) analysis. Fluorescently labeled PCR products were purified using the Wizard $^{\circledR}$ PCR Preps DNA purification system (Promega) and subsequently digested with $20 \mathrm{U} \mathrm{MspI} \mathrm{(Boehringer} \mathrm{Mannheim} \mathrm{Bio-}$ chemicals) at $37^{\circ} \mathrm{C}$ for $6 \mathrm{~h}$. Aliquots of digested products $(10 \mathrm{ml})$ were mixed with $0.5 \mathrm{ml}$ of internal size standard (ET550-R, Amersham Biosciences), denatured $\left(2 \min\right.$ at $\left.95^{\circ} \mathrm{C}\right)$ and snap-cooled on ice before capillary electrophoresis on a MegaBACE ${ }^{\mathrm{TM}}$ genetic analyzer (Amersham Biosciences) operating in Genotyping mode. After electrophoresis, the length of fluorescently labeled terminal restriction fragments was determined using the Genetic Profiler software package (Amersham Biosciences).

Larval culture. Broodstocks of the polychaete Hydroides elegans and the barnacles Balanus amphitrite and B. trigonus were collected from Port Shelter, Hong Kong. For $H$. elegans, gametes released from adults were fertilized in FSW; larvae were raised to the competent stage (i.e. a physiological stage in which larvae are able to settle) in batch culture on a diet of the flagellate Isochrysis galbana (Tahitian strain) at $25^{\circ} \mathrm{C}$ according to the procedures described in Lau \& Qian (2001). For B. amphitrite and
B. trigonus, larvae released from adults were raised to the competent stage in batch cultures on a diet of the diatom Chaetoceros gracilis at $25^{\circ} \mathrm{C}$ according to Thiyagarajan et al. (2003). The competent larvae of $B$. amphitrite were allowed to age for $2 \mathrm{~d}$ before the assays, whereas those of $B$. trigonus were used in the assays within $12 \mathrm{~h}$ upon transformation to the competent stage. The power of assays with $B$. amphitrite can be greatly improved by using competent larvae aged for $2 \mathrm{~d}$ because the larvae become more 'desperate' to settle due to the depletion of energy reserve and yet not loosing their ability to distinguish between substrata (Rittschof et al. 1984, Harder et al. 2001). In contrast, competent larvae of $B$. trigonus usually suffer from high mortality during aging (Thiyagarajan et al. 2003). Therefore, newly transformed competent larvae of $B$. trigonus were used in the assays.

Larval settlement assays. All assays were conducted twice, once using the biofilms developed in March 2003 (Batch 1) and once using biofilms developed in April 2003 (Batch 2). On each occasion, 5 replicates were used per treatment. For barnacles, the assays were conducted in a 'double-dish' setup constructed by connecting (using parafilm) a diprinsed biofilmed dish (as treatment) and an unfilmed dish (as control) into a single unit along with 20 to 30 larvae in $5 \mathrm{ml}$ autoclaved FSW (35\%) (Harder et al. 2001). Subsequently, the paired dishes were then completely filled with autoclaved FSW using a syringe. After $24 \mathrm{~h}$ incubation at $25^{\circ} \mathrm{C}$ in a vertical position, the number of barnacle larvae settled on each dish was determined using a dissecting microscope. Traditionally, assays with barnacle larvae were conducted in a single dish format as for Hydroides elegans (see below). However, due to the surface property of barnacle larvae, the air-water interface entraps significant amount of larvae and causes severe bias. In contrast, the lack of air-water interface in the double-dish setup can improve the reliability of the assays (Harder et al. 2001). Since the larvae of $H$. elegans are never trapped at the airwater interface, the bioassays for $H$. elegans were conducted in a conventional, single dish format for simplicity (Lau \& Qian 2001). Briefly, the biofilmed dishes were dip-rinsed 10 times in autoclaved FSW $(35 \%)$ and filled with $5 \mathrm{ml}$ of autoclaved FSW $(3 \%)$ along with 20 to 30 competent larvae. After $12 \mathrm{~h}$ of incubation at $25^{\circ} \mathrm{C}$, the number of settled larvae was determined using a dissecting microscope. A positive control was dip-rinsed, $5 \mathrm{~d}$ old biofilms developed at the HKUST pier; the ambient seawater temperature and salinity were ca. 23 to $25^{\circ} \mathrm{C}$ and 33 to $35 \%$, respectively. Unfilmed dishes served as a negative control. 
Statistical analysis. Biomass and bacterial abundance in biofilms: Data for biomass and bacterial abundance were checked for normality using the Shapiro-Wilk's test and for homogeneity of variance using the Cochran's C-test. Since a 3-way ANOVA revealed no significant batch temperature salinity interaction, data from the 2 batches of assays were pooled and analyzed using a 2-way ANOVA (temperature $\times$ salinity).

Bacterial community composition: Band patterns in DGGE gels and peak patterns in T-RFLP chromatographs were transformed to binary character tables ( 1 or 0 corresponding to the presence or absence of a given band/peak in a biofilm sample) using the GelCompar II program package (Applied Maths) and the Genetic Profiler package, respectively. A similarity matrix was constructed based on the total number of bands/peaks observed in all biofilm bacterial communities and the presence or absence of these bands/ peaks in each community. Agglomerative hierarchical clustering was performed using UPGMA (unweighted pair group method using arithmetic averages) and the distances (i.e. similarity) among communities were displayed as a dendrogram.

Larval settlement: The mean percent settlement data for Hydroides elegans were arcsine-transformed and tested for normality and homogeneity of variance. Since a 3-way ANOVA revealed no significant batch temperature salinity interaction, data from the 2 batches of assays were pooled and analyzed using a 2-way ANOVA (temperature salinity). For the assays with Balanus amphitrite and B. trigonus, the number of larvae that settled on each of the paired dishes was compared to the null hypothesis of 1:1 distribution among the 2 dishes using replicated G-tests for goodness of fit. The $G$-value was calculated as a measure of heterogeneity among the replicate paired dishes within an assay as well as between the 2 batches of assays. Homogenous data sets were pooled and corresponding G-values were transformed by the Williams' correction. Furthermore, the relationship between percent larval settlement and bacterial density/biomass of the biofilms was determined using the Spearman rank order correlation analysis.

\section{RESULTS}

\section{Bacterial density of biofilms}

After 20 d development, bacterial densities in the 2 batches of biofilms ranged from $12.5 \times 10^{3}$ to $29.1 \times 10^{3}$ cells $\mathrm{mm}^{-2}$ (Table 1 ); total biomass ranged from 0.06 to $0.27 \mathrm{mg} \mathrm{mm}^{-2}$ (Table 1). Salinity had a significant effect on bacterial density $(F=13.027, \mathrm{p}<0.001)$, but not on
Table 1. Bacterial density and biomass of biofilms developed in different salinity and temperature treatments for 2 batches of the assays. Data presented are mean \pm 1 SD of 3 replicates in each batch of assays without transformation

\begin{tabular}{|cccc|}
\hline $\begin{array}{l}\text { Salinity } \\
(\%)\end{array}$ & $\begin{array}{c}\text { Temp. } \\
\left({ }^{\circ} \mathrm{C}\right)\end{array}$ & $\begin{array}{c}\text { Bacterial } \\
\left(10^{3} \text { cells }\right. \\
\left.\mathrm{mm}^{-2}\right)\end{array}$ & $\begin{array}{c}\text { Biomass } \\
\left(\mathrm{mg} \mathrm{mm}^{-2}\right)\end{array}$ \\
\hline Batch 1 & & & \\
34 & 30 & $21.2 \pm 4.9$ & $0.16 \pm 0.01$ \\
27 & 30 & $18.5 \pm 4.6$ & $0.15 \pm 0.01$ \\
20 & 30 & $18.8 \pm 5.1$ & $0.15 \pm 0.03$ \\
34 & 23 & $25.6 \pm 2.8$ & $0.14 \pm 0.02$ \\
27 & 23 & $22.8 \pm 4.5$ & $0.17 \pm 0.03$ \\
20 & 23 & $15.8 \pm 1.6$ & $0.15 \pm 0.01$ \\
34 & 16 & $29.1 \pm 1.8$ & $0.07 \pm 0.03$ \\
27 & 16 & $26.8 \pm 0.6$ & $0.08 \pm 0.01$ \\
20 & 16 & $14.3 \pm 1.4$ & $0.07 \pm 0.01$ \\
Batch 2 & & & \\
34 & 30 & $23.1 \pm 5.9$ & $0.24 \pm 0.05$ \\
27 & 30 & $17.7 \pm 2.8$ & $0.27 \pm 0.09$ \\
20 & 30 & $19.2 \pm 4.2$ & $0.12 \pm 0.04$ \\
34 & 23 & $18.9 \pm 1.8$ & $0.06 \pm 0.01$ \\
27 & 23 & $19.6 \pm 2.3$ & $0.08 \pm 0.04$ \\
20 & 23 & $12.5 \pm 1.2$ & $0.15 \pm 0.11$ \\
34 & 16 & $19.2 \pm 2.4$ & $0.20 \pm 0.07$ \\
27 & 16 & $15.6 \pm 2.6$ & $0.17 \pm 0.05$ \\
20 & 16 & $12.8 \pm 1.7$ & $0.14 \pm 0.03$ \\
& & & \\
\hline
\end{tabular}

total biomass $(F=0.575, \mathrm{p}=0.567)$. Conversely, temperature had a significant effect on biomass $(F=4.654$, $\mathrm{p}=0.015)$, but not on bacterial density $(F=0.079, \mathrm{p}=$ $0.924)$. Salinity and temperature had no interactive effect on bacterial density $(F=2.110, \mathrm{p}=0.095)$ or on biomass $(F=1.431, \mathrm{p}=0.239)$.

\section{Bacterial community composition}

Visual inspections revealed that biofilms from the same treatment had different DGGE profiles within each of the 2 experimental batches (Fig. 1). Nevertheless, cluster analysis indicated that, in both batches of biofilms, the lowest temperature treatment $\left(16^{\circ} \mathrm{C}\right)$ resulted in bacterial communities highly distant $(<35 \%$ similarity) from those developed in the higher temperature treatments (23 and $30^{\circ} \mathrm{C}$ ) (Fig. 2a,b). Bacterial communities in the higher temperature treatments (23 and $30^{\circ} \mathrm{C}$ ) were mostly segregated into small clusters according to salinity.

T-RFLP analysis resulted in 12 to 29 terminal restriction fragments (TRFs) in Batch 1 biofilms (Table 2), and 11 to 28 TRFs in Batch 2 biofilms (Table 3). Similar to that of the DGGE profiles, cluster analysis of T-RFLP profiles also distinguished bacterial communities developed at $16^{\circ} \mathrm{C}$ from those at 23 or $30^{\circ} \mathrm{C}(<45 \%$ similarity; Fig. 2c,d). 

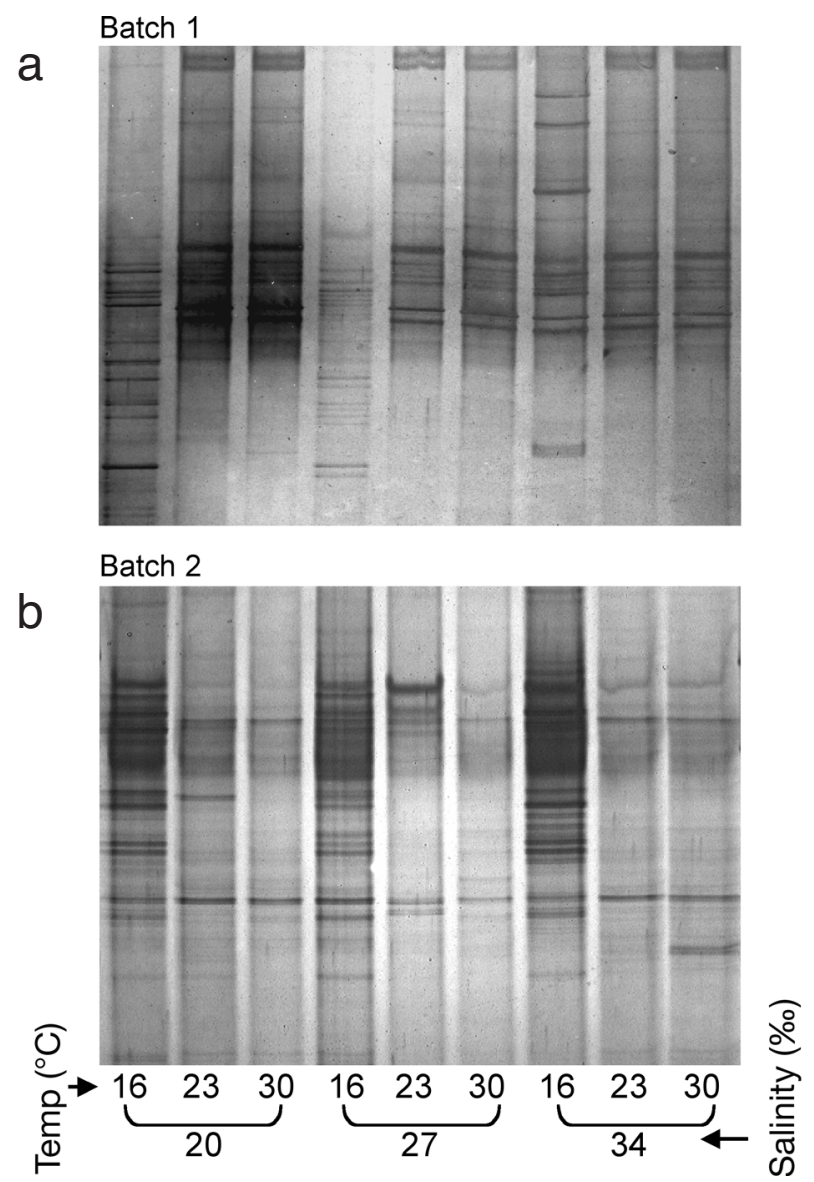

Fig. 1. DGGE profile of bacterial communities in biofilms developed in different salinity and temperature treatments in each batch of larval settlement assays. The range of denaturant gradient in the gel images was (a) 45 to (b) $60 \%$. Electrophoresis was conducted at $100 \mathrm{~V}$ for $17 \mathrm{~h}$

\section{Larval settlement}

\section{Balanus amphitrite}

A goodness of fit $G$-test performed with pooled data from Batch 1 and 2 assays indicated that Balanus amphitrite larvae did not distinguish between an unfilmed surface and any of the biofilms developed at $16^{\circ} \mathrm{C}$ (Fig. 3, Table 4). However, larvae settled at a significantly higher proportion on all biofilms developed at 23 and $3^{\circ} \mathrm{C}$ than on the unfilmed surface (Fig. 3, Table 4).

\section{Balanus trigonus}

A goodness of fit $G$-test performed with pooled data from Batch 1 and 2 assays indicated that larvae of Balanus trigonus settled preferentially on biofilms developed at either 23 or $30^{\circ} \mathrm{C}$ over unfilmed surfaces, except for biofilms developed in the $34 \% / 30^{\circ} \mathrm{C}$ treatment (Fig. 4, Table 4). However, the larvae preferred unfilmed surfaces over biofilms developed in the $16^{\circ} \mathrm{C}$ treatments (Fig. 4, Table 4).

\section{Hydroides elegans}

In both batches of assays, mean percent larval settlement of Hydroides elegans after $12 \mathrm{~h}$ was $\geq 91.7 \%$ in the positive control (dish with natural biofilm) and $\leq 4.2 \%$ in the negative control (unfilmed dish) (Fig. 5). The mean percent larval settlement on biofilms developed in different salinity and temperature treatments ranged from 80.0 to $96.7 \%$. Generally, larval settlement varied among biofilms developed at different salinities $(F=19.240, \mathrm{p}<0.001)$, but not among those developed at different temperatures $(F=0.050, \mathrm{p}=$ 0.953). The 2 factors (i.e. biofilms developed at different salinity and temperature) had no interactive effect on larval settlement $(F=0.210, \mathrm{p}=0.930)$.

\section{Correlation of larval settlement with biomass and bacterial density}

The Spearman rank order correlation analysis indicated that the percent larval settlement of Hydroides elegans was positively correlated with bacterial density but not with biomass of the biofilms (Table 5). In contrast, the percent larval settlement of Balanus amphitrite and of $B$. trignous were unrelated to either bacterial density or biomass of the biofilms (Table 5).

\section{DISCUSSION}

The $3 \times 3$ array of salinity and temperature treatments resulted in biofilms that differed qualitatively in terms of bacterial community composition (Figs. 1 \& 2 , Tables 2 \& 3) and quantitatively in terms of bacterial density and total biomass (Table 1). Particularly, the 2 DNA fingerprinting techniques DGGE and T-RFLP demonstrated substantial differences in bacterial community composition between the biofilms developed at high (i.e. 23 and $30^{\circ} \mathrm{C}$ ) and low (i.e. $16^{\circ} \mathrm{C}$ ) temperatures; salinity seemed not to have any profound effect.

The evaluation of T-RFLP and DGGE data in concert provided some possible explanations as to what might have caused the temperature-induced shift in bacterial community composition. T-RFLP analysis detected a higher number of operational taxonomic units (OTUs; i.e. bands/peaks detected by DNA fingerprinting techniques) for biofilms developed at higher temperatures (both batches), suggesting that the indigenous 
(a) Percent similarity

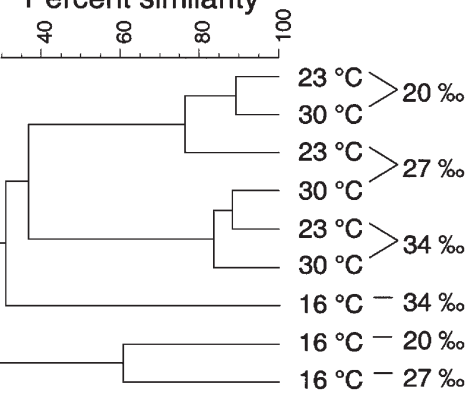

(b)

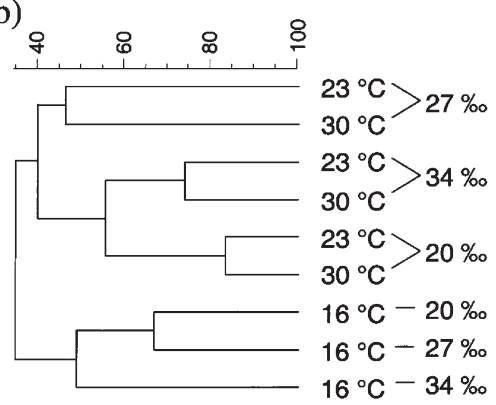

(c)

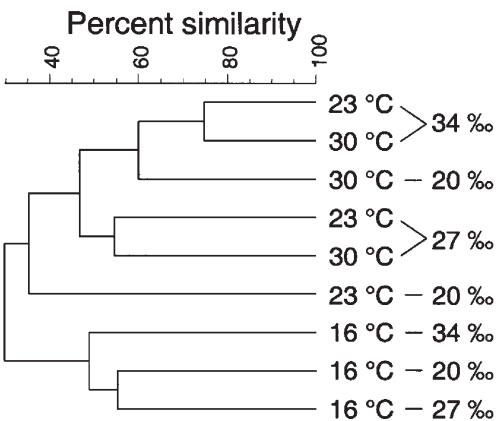

(d)

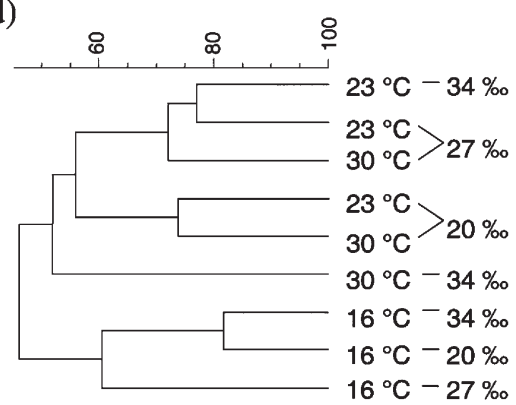

bacterial colonizers in the seawater taken for the experiments might be mainly mesophilic. In contrast, DGGE detected a large number of OTUs exclusive to biofilms of the $16^{\circ} \mathrm{C}$ treatments (both batches), suggesting that the observed community shift might be due not only to the suppression of mesophilic bacteria by low temperature, but also to the opening of niches to bacteria that were retarded to attach and/or grow at higher temperatures. The observed bacterial community shift was consistent among the 2 batches of biofilms, although the position and abundance of OTUs in each treatment differed between each batch. In general, bacterial communities in Batch 1 biofilms were more diverse, as indicated by the generally higher number of OTUs detected by both DNA fingerprinting techniques. The batch-to-batch varia-

Fig. 2. Similarity of DGGE (a: Batch 1; b: Batch 2) and T-RFLP (c: Batch 1; d: Batch 2) profiles among the bacterial communities developed in a $3 \times 3$ array of salinity and temperature treatments in each batch of larval settlement assays

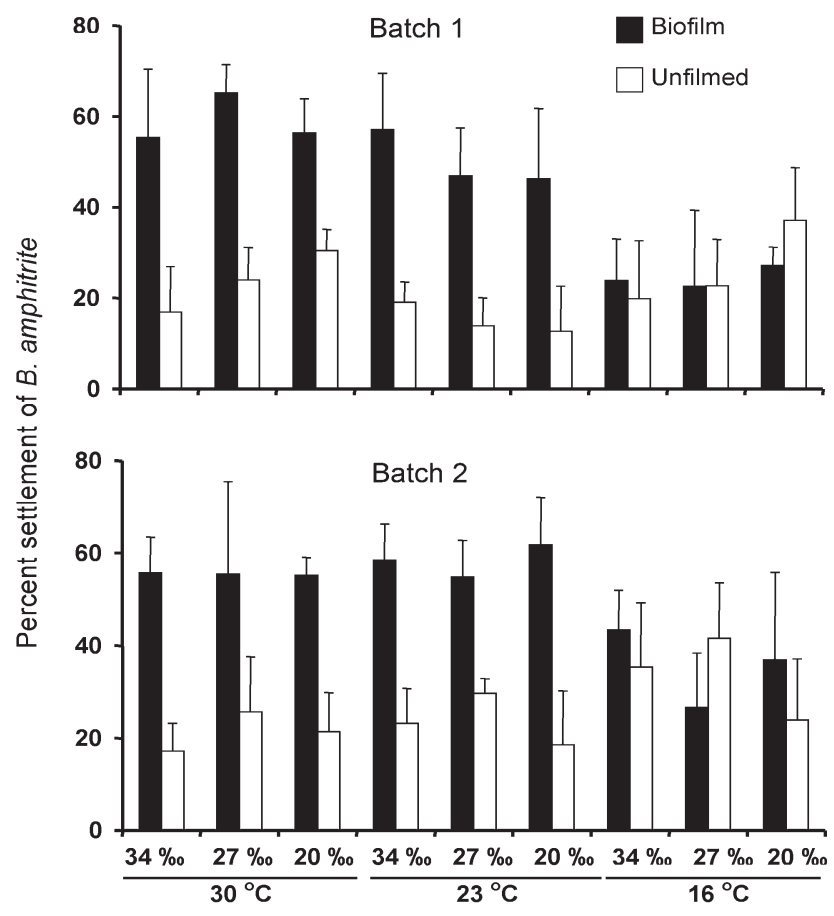

Salinity and temperature for biofilm development

Fig. 3. Balanus amphitrite. Percent larval settlement after $24 \mathrm{~h}$ incubation in a double-dish setup containing a biofilmed dish and an unfilmed dish. Biofilms were developed in a $3 \times 3$ array of salinity $(20,27$ and $34 \%)$ and temperature $(16,23$ and $30^{\circ} \mathrm{C}$ ) treatments. Data presented are mean $+1 \mathrm{SD}$ of 5 replicates in each batch of assays without transformation
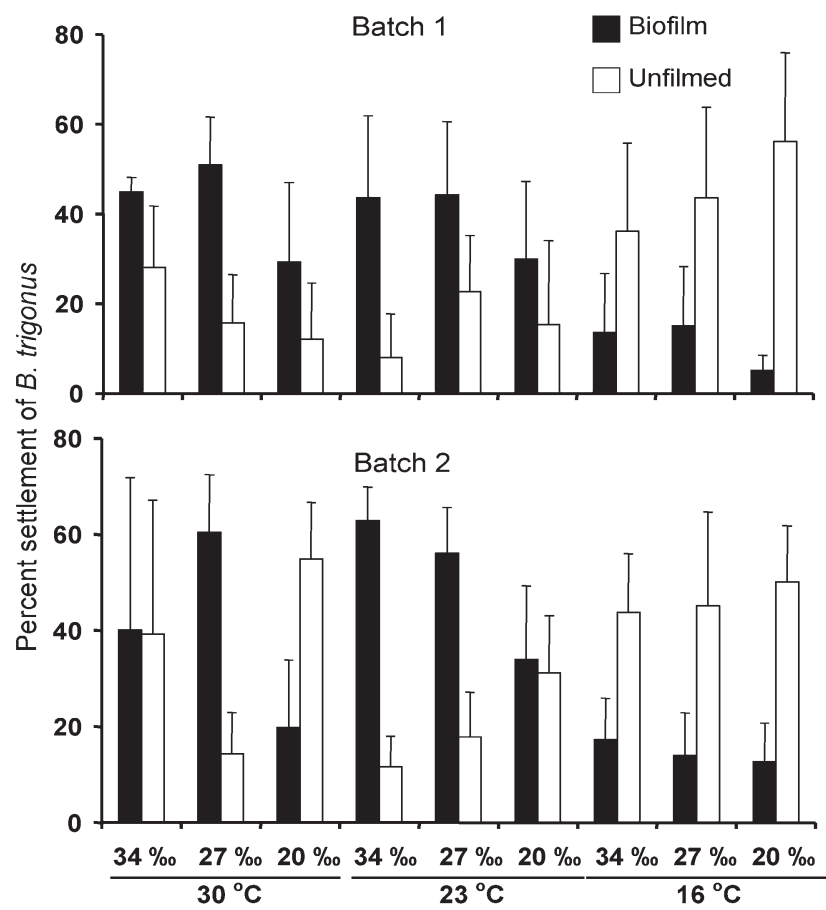

Salinity and temperature for biofilm development

Fig. 4. Balanus trigonus. Percent larval settlement after $24 \mathrm{~h}$ incubation in a double-dish setup containing a biofilmed dish and an unfilmed dish. Biofilms were developed in a $3 \times 3$ array of salinity $(20,27$ and $34 \%$ ) and temperature $(16,23$ and $30^{\circ} \mathrm{C}$ ) treatments. Data presented are mean $+1 \mathrm{SD}$ of 5 replicates in each batch of assays without transformation 
Table 2. T-RFLP profile of bacterial communities in Batch 1 of biofilms developed in different salinity and temperature treatments. Individual TRFs are indicated by fragment size (bp). Entries without a dash (-) indicate TRFs of particular sizes occurring in a given biofilm; values therein represent the number of discernible TRFs occurring in a given fragment size range. Total number of TRFs in each biofilm is in bold

\begin{tabular}{|c|c|c|c|c|c|c|c|c|c|}
\hline $\begin{array}{l}\text { TRF } \\
\text { (bp) }\end{array}$ & $20 \%$ & $\begin{array}{l}16^{\circ} \mathrm{C} \\
27 \% o\end{array}$ & $34 \%$ & $20 \%$ & $\begin{array}{l}23^{\circ} \mathrm{C} \\
27 \% \text { o }\end{array}$ & $34 \%$ & $20 \%$ & $\begin{array}{l}30^{\circ} \mathrm{C} \\
27 \% \text { o }\end{array}$ & $34 \%$ \\
\hline $36-40$ & - & - & 2 & - & - & 4 & - & 2 & 1 \\
\hline 41 & - & - & - & - & - & - & 1 & - & 1 \\
\hline 42 & 1 & 1 & - & 1 & - & 1 & - & - & - \\
\hline 43 & - & - & - & - & - & 1 & - & - & - \\
\hline 64 & - & - & - & - & 1 & - & 1 & - & - \\
\hline 71 & - & - & - & - & 1 & - & - & - & - \\
\hline $74-78$ & - & 1 & - & - & 1 & - & - & - & - \\
\hline $83-85$ & - & - & - & 1 & - & 1 & - & - & - \\
\hline 99-104 & 3 & - & - & - & - & - & - & - & - \\
\hline $123-146$ & - & - & - & 8 & 4 & 7 & 2 & 1 & 6 \\
\hline $155-157$ & - & - & - & 2 & - & - & - & - & - \\
\hline $160-167$ & - & - & - & 1 & 2 & 2 & 1 & 2 & 2 \\
\hline 179 & - & - & - & 1 & - & - & - & - & - \\
\hline 184 & - & - & - & - & - & 1 & - & - & - \\
\hline 194 & - & 1 & - & - & 1 & - & - & - & - \\
\hline 195 & - & 1 & 1 & - & - & - & - & - & - \\
\hline 196 & - & - & - & - & 1 & - & - & - & - \\
\hline 197 & - & - & - & 1 & - & - & - & - & - \\
\hline 206 & - & 1 & - & - & - & - & - & - & - \\
\hline 207 & 1 & - & - & - & - & - & - & - & - \\
\hline $209-214$ & 3 & 3 & 3 & 3 & 2 & 2 & 2 & 2 & 3 \\
\hline 215 & 1 & 1 & - & - & - & - & - & - & - \\
\hline 216 & - & 1 & - & - & - & - & - & - & - \\
\hline 223 & - & - & - & - & - & - & - & 1 & - \\
\hline 225 & - & - & - & - & - & 1 & 1 & - & - \\
\hline 226 & - & - & - & - & - & - & - & - & 1 \\
\hline $234-241$ & 3 & 6 & 3 & 4 & 3 & 4 & 4 & 5 & 4 \\
\hline 254 & - & 1 & - & - & - & - & - & - & - \\
\hline 270 & 1 & 1 & - & - & - & - & - & - & - \\
\hline $310-316$ & - & - & - & 1 & 2 & 2 & 2 & 2 & 3 \\
\hline $322-324$ & - & - & - & - & - & - & - & 1 & 1 \\
\hline $332-340$ & - & - & - & 3 & 3 & 3 & 2 & 4 & 3 \\
\hline $405-407$ & - & 3 & - & - & - & - & - & - & - \\
\hline 523 & 1 & - & 1 & - & - & 1 & - & - & - \\
\hline 524 & - & - & - & 1 & - & - & - & - & - \\
\hline 526 & - & - & - & - & - & - & - & 1 & - \\
\hline $528-530$ & - & - & - & - & 1 & - & 2 & 2 & 1 \\
\hline 562 & 1 & - & - & - & - & - & - & - & - \\
\hline 563 & - & 1 & - & - & - & - & - & - & - \\
\hline 564 & 1 & 1 & - & - & 1 & - & - & - & - \\
\hline 565 & - & 1 & - & - & - & - & - & - & - \\
\hline 566 & - & - & - & - & - & - & - & 1 & - \\
\hline 590 & - & 1 & - & - & - & - & - & - & - \\
\hline 570 & - & - & 1 & - & - & - & - & - & - \\
\hline $572-575$ & - & - & - & - & - & - & 2 & - & 2 \\
\hline $582-583$ & 1 & 2 & - & - & - & - & - & - & - \\
\hline $585-588$ & - & 2 & 1 & - & - & - & - & - & - \\
\hline 595 & - & - & - & - & - & - & - & - & 1 \\
\hline Total & 17 & 29 & 12 & 28 & 26 & 27 & 19 & 24 & 29 \\
\hline
\end{tabular}

DNA fingerprinting techniques are valuable tools for the characterization of environmental bacterial communities, but different techniques have different limitations and biases. Therefore, we used 2 different techniques (DGGE and T-RFLP) to reach a presumably more reliable description of bacterial community composition (Hoffmann et al. 2002). T-RFLP cannot differentiate closely related DNA sequences, which are likely to have the same terminal restriction site, and thus may reduce the number of detectable OTUs. However, T-RFLP is also prone to overestimation of bacterial diversity due to pseudo-TRF formation (i.e. single stranded amplicons that are recalcitrant to restriction enzyme digestion) (Egert \& Friedrich 2003). In contrast, DGGE can resolve closely related DNA sequences better than T-RFLP (Casamayor et al. 2002), but is more affected by heteroduplexe formation and rRNA operon heterogeneity (Muyzer 1998), which can increase the number of OTUs artificially. It is not known to what extent our analysis was affected by the limitations of the 2 techniques, and also by possible biases due to differential extraction of DNA from different bacterial populations (Martin-Laurent et al. 2001) as well as preferential PCR amplification of numerically dominant DNA templates (Polz \& Cavanaugh 1998). Nevertheless, the bacterial community composition obtained by the 2 techniques, each using primers targeting a different region of the 16S rRNA gene (V3 to V5 for T-RFLP, and V6 to V8 for DGGE), clearly indicated a temperature-induced shift in bacterial community composition in both batches of biofilms. In addition to bacteria, a small population of diatoms was present in all biofilms (data not shown); however, the cell density $\left(<100\right.$ cell $\mathrm{mm}^{-2}$ ) was lower than those having known effects on larval settlement of the 2 barnacles and Hydroides elegans (Harder et al. 2002, authors' unpubl. data). Therefore, these tions in bacterial community composition may be due to possible intrinsic temporal variation of the indigenous bacterial population in the seawater taken for the experiments. biofilms were deemed appropriate for investigating whether the larvae of $H$. elegans, Balanus amphitrite and $B$. trigonus responded differentially to biofilms composed of different bacterial communities. 
Table 3. T-RFLP profile of bacterial communities in Batch 2 of biofilms developed in different salinity and temperature treatments. Individual TRFs are indicated by fragment size (bp). Entries without a dash (-) indicate TRFs of particular sizes occurring in a given biofilm; values therein represent the number of discernible TRFs occurring in a given fragment size range. Total number of TRFs in each biofilm is in bold

\begin{tabular}{|c|c|c|c|c|c|c|c|c|c|}
\hline $\begin{array}{l}\text { TRF } \\
\text { (bp) }\end{array}$ & $20 \%$ & $\begin{array}{l}16^{\circ} \mathrm{C} \\
27 \% \text { o }\end{array}$ & $34 \%$ & $20 \%$ & $\begin{array}{l}23^{\circ} \mathrm{C} \\
27 \% \text { o }\end{array}$ & $34 \%$ & $20 \%$ & $\begin{array}{l}30^{\circ} \mathrm{C} \\
27 \% \text { o }\end{array}$ & $34 \%$ \\
\hline 30-32 & 3 & - & - & - & - & 3 & 3 & 3 & - \\
\hline 33 & - & - & - & - & - & & 1 & 1 & - \\
\hline $39-40$ & 2 & 1 & 3 & 1 & 1 & 1 & - & 1 & 1 \\
\hline 41 & - & - & - & - & 1 & 1 & - & - & 1 \\
\hline 42 & 1 & 1 & 1 & - & 1 & - & 1 & 1 & 1 \\
\hline 43 & - & - & - & 1 & 1 & - & 1 & 1 & - \\
\hline 45 & - & - & - & 1 & - & - & - & - & - \\
\hline 61 & - & - & - & 1 & - & - & - & - & - \\
\hline $62-64$ & 2 & - & - & 1 & 1 & 2 & 2 & 2 & 1 \\
\hline 65 & - & - & - & - & 1 & - & - & - & - \\
\hline $67-68$ & 1 & 1 & 1 & 1 & 1 & 1 & 1 & 1 & 1 \\
\hline 71 & - & - & - & - & - & 1 & 1 & 1 & - \\
\hline 72 & - & - & - & 1 & - & - & - & - & - \\
\hline $76-79$ & - & 1 & - & 1 & - & - & 1 & - & 1 \\
\hline 80 & - & - & - & - & 1 & - & - & 1 & - \\
\hline $85-86$ & - & - & - & 1 & 1 & 1 & 1 & - & - \\
\hline $94-104$ & - & - & - & - & - & - & 2 & - & 3 \\
\hline 118 & - & - & - & - & - & - & - & - & 1 \\
\hline 127 & - & - & - & 1 & 1 & - & 1 & 1 & - \\
\hline 129 & - & 1 & - & - & - & - & - & - & - \\
\hline 135 & 1 & - & 1 & - & - & - & - & - & - \\
\hline 136 & - & 1 & - & - & - & - & - & - & - \\
\hline 137 & 1 & - & 1 & - & 1 & 1 & 1 & 1 & 1 \\
\hline 139 & - & 1 & - & - & - & - & - & - & - \\
\hline 140 & 1 & - & 1 & - & - & 1 & 1 & 1 & 1 \\
\hline 141 & - & 1 & - & - & - & - & - & - & - \\
\hline 149 & - & - & - & - & - & - & - & 1 & 1 \\
\hline 150 & - & - & - & 1 & - & - & - & - & - \\
\hline 159 & - & 1 & - & - & - & - & - & - & - \\
\hline 161 & - & - & - & - & - & - & - & - & 1 \\
\hline $163-166$ & 3 & 3 & 2 & 1 & 2 & 2 & 1 & 1 & 3 \\
\hline 190 & - & - & - & - & 1 & - & - & 1 & - \\
\hline 191 & - & - & - & - & - & - & - & - & 1 \\
\hline 194 & - & - & - & - & - & - & - & - & 1 \\
\hline 195 & - & - & - & - & - & - & 1 & - & 1 \\
\hline 196 & - & 1 & - & - & - & - & - & - & - \\
\hline 216 & - & - & 1 & - & - & - & - & - & - \\
\hline 223 & - & - & - & 1 & 1 & - & - & 1 & - \\
\hline 244 & - & 1 & - & - & - & - & - & - & - \\
\hline 273 & 1 & - & - & 1 & - & 1 & 1 & 1 & 1 \\
\hline 275 & - & - & - & - & - & 1 & - & - & - \\
\hline 324 & - & - & - & - & - & - & - & - & 1 \\
\hline $378-379$ & - & - & - & 1 & - & 1 & 1 & 1 & 1 \\
\hline 434 & - & - & - & - & - & - & - & - & 1 \\
\hline $562-564$ & - & - & - & - & - & 3 & - & - & 2 \\
\hline $569-570$ & - & - & - & - & - & - & - & - & 2 \\
\hline 587 & - & 1 & - & - & - & 1 & - & - & 1 \\
\hline $589-590$ & - & - & - & - & - & 2 & - & - & 1 \\
\hline Total & 16 & 15 & 11 & 15 & 15 & 23 & 21 & 23 & 28 \\
\hline
\end{tabular}

ing on the biofilm being tested (Figs. 3 \& 4, Table 4). Biofilms developed at 23 and $30^{\circ} \mathrm{C}$ attracted larval settlement of both barnacle species. However, those developed at $16^{\circ} \mathrm{C}$ either repelled $(B$. trigonus) or did not affect (B. amphitrite) larval settlement. This settlement response did not correlate with the biomass or bacterial density of the biofilms, but coincided well with the clearly observable temperature-induced shift in bacterial community composition in the biofilms. These results suggest that the bacterial community composition of biofilms has strong influences on larval settlement of these 2 barnacle species.

The preferential barnacle settlement on biofilms developed at higher temperatures may be due to the presence of one or a few settlement-inducing bacterial species. Conversely, the avoidance of biofilms developed at $16^{\circ} \mathrm{C}$ by Balanus trigonus larvae may be due to the presence of settlementinhibiting bacterial species. The different responses of $B$. amphitrite (neutral) and $B$. trigonus (avoidance) larvae to the same biofilms developed at $16^{\circ} \mathrm{C}$ suggest that either the 2 barnacle larvae responded to diverse bacterial species in the same biofilm or the same bacteria elicited varying responses in the 2 larvae. Although our data suggest a possible role of bacterial community composition as a mediator of barnacle larval settlement, we cannot rule out the possible role(s) of gene expression, physiological response and production of compounds by bacteria and other biofilm components, and especially that the biofilms might be faced with possible stresses due to sudden changes in salinity and temperature during the setting up of the assays (e.g. from $16^{\circ} \mathrm{C} / 20 \%$ for biofilm development to $25^{\circ} \mathrm{C} / 33 \%$ for the larval settlement assay).

In contrast to the 2 barnacles, the presence of a biofilm is a pre-requisite

Larvae of the barnacles Balanus amphitrite and $B$. trigonus can settle with or without the presence of a biofilm (Wieczorek \& Todd 1998). The assays in this study demonstrated that biofilms could attract, repel or not affect settlement of the 2 barnacle species, depend- for larval settlement of Hydroides elegans (Lau \& Qian 1997, Beckmann et al. 1999). This is shown by the clearly contrasting larval response to the natural biofilm and unfilmed controls (Fig. 5). H. elegans larval settlement varied among the biofilms developed under 
Table 4. Results of log-likelihood ratio analysis used to test the preference of barnacles Banalus amphitrite and B. trignous larvae to settle on unfilmed surfaces or biofilms developed in different salinity and temperature treatments. Data for the analysis were pooled from the 2 batches of assays. The critical value for this log-likelihood test is $G_{\text {adj }}(0.05,1)=3.841$. $\mathrm{p}$-values are denoted with the degree of freedom (df). A significant $p$-value (indicated by ${ }^{*}$ ) means the ratio of larval settlement on the biofilm and the pre-sterile surface deviated from the expected 1:1 ratio

\begin{tabular}{|lrrr|}
\hline \multicolumn{2}{c}{ Treatment } & \multicolumn{3}{c|}{ Log-likeihood ratio test } \\
Salinity (\%) & Temp. $\left({ }^{\circ} \mathrm{C}\right)$ & $G_{\text {adj }}$ & $\mathrm{p}(\mathrm{df})$ \\
\hline B. amphitrite & & & \\
34 & 30 & 188.23 & $<0.001(1)^{*}$ \\
27 & 30 & 150.94 & $<0.001(1)^{*}$ \\
20 & 30 & 93.93 & $<0.001(1)^{*}$ \\
34 & 23 & 94.65 & $<0.001(1)^{*}$ \\
27 & 23 & 61.91 & $<0.001(1)^{*}$ \\
20 & 23 & 110.21 & $<0.001(1)^{*}$ \\
34 & 16 & 3.57 & $>0.050(1)$ \\
27 & 16 & 2.81 & $>0.050(1)$ \\
20 & 16 & 0.25 & $>0.050(1)$ \\
B. trigonus & & & \\
34 & 30 & 1.69 & $>0.050(1)$ \\
27 & 30 & 98.21 & $<0.001(1)^{*}$ \\
20 & 30 & 9.45 & $<0.001(1)^{*}$ \\
34 & 23 & 170.29 & $<0.001(1)^{*}$ \\
27 & 23 & 66.17 & $<0.001(1)^{*}$ \\
20 & 23 & 5.41 & $<0.050(1)^{*}$ \\
34 & 16 & 74.11 & $<0.001(1)^{*}$ \\
27 & 16 & 141.95 & $<0.001(1)^{*}$ \\
20 & 16 & 50.95 & $<0.001(1)^{*}$ \\
& & & \\
\hline
\end{tabular}

Table 5. Correlations between percent larval settlement (Hydroides elegans, Balanus amphitrite and B. trigonus) and 2 quantitative biofilm attributes (bacterial density and total biomass). Data were pooled from all treatments in the 2 batches of assays and tested by the Spearman rank order correlation analysis. $\mathrm{p}<0.050$ indicates a significant correlation

\begin{tabular}{|c|c|c|c|c|}
\hline $\begin{array}{l}\text { Biofilm } \\
\text { attribute }\end{array}$ & & $\begin{array}{l}\text { Percent larval } \\
\text { settlement }\end{array}$ & $r^{2}$ & $\mathrm{p}$-value \\
\hline Bacterial density & vs. & $\begin{array}{l}\text { H. elegans } \\
\text { B. amphitrite } \\
\text { B. trigonus }\end{array}$ & $\begin{array}{r}0.74 \\
-0.13 \\
-0.08\end{array}$ & $\begin{array}{r}<0.001 \\
0.604 \\
0.735\end{array}$ \\
\hline Total biomass & vs. & $\begin{array}{l}\text { H. elegans } \\
\text { B. amphitrite } \\
\text { B. trigonus }\end{array}$ & $\begin{array}{l}0.03 \\
0.04 \\
0.19\end{array}$ & $\begin{array}{l}0.901 \\
0.868 \\
0.443\end{array}$ \\
\hline
\end{tabular}

different salinities but not among those developed at different temperatures. This settlement response appeared to be moderately correlated with bacterial density but not with biomass of the biofilms (Table 5). More importantly, this settlement response had no apparent relationship with the temperature-induced shift in bacterial community composition in the bio-

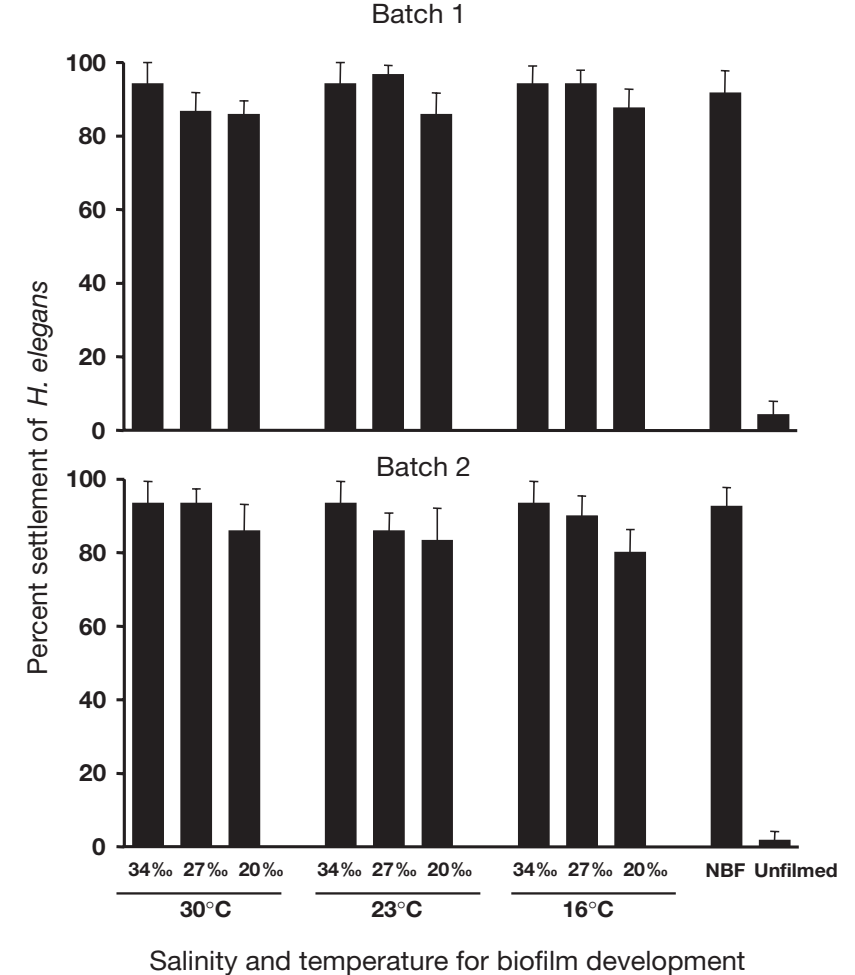

Fig. 5. Hydroides elegans. Percent larval settlement after $12 \mathrm{~h}$ incubation in dishes containing biofilms developed in different salinity $(20,27$ and $34 \%)$ and temperature $(16,23$ and $30^{\circ} \mathrm{C}$ ) treatments. Controls were unfilmed dishes and $5 \mathrm{~d}$ old biofilms developed naturally in the sea (NBF). Data presented are mean +1 SD of 5 replicates in each batch of assays without transformation

films, suggesting that bacterial community composition had no apparent effect on larval settlement of $H$. elegans. Our finding is the opposite of what has been commonly hypothesized-bacterial species composition in biofilms can influence larval settlement of H. elegans (Lau \& Qian 1997, Huang \& Hadfield 2003). This hypothesis is largely based on the observation that monospecies biofilms derived from different bacterial species can induce diverse levels of larval settlement in $H$. elegans, varying from none to as high as natural biofilm (Unabia \& Hadfield 1999, Lau \& Qian 2001). However, our data cannot rule out the possibility that larval settlement of $H$. elegans was induced by one or a few bacterial species that commonly occurred in all the tested biofilms. It is also uncertain whether the commonly observed bacterial cell density dependent larval settlement was mediated by the total bacterial population or one or a few inductive bacterial species (Hadfield et al. 1994, Beckmann et al. 1999, Huang \& Hadfield 2003, the present study).

The observed differences in biofilm selectivity by the 2 barnacles and Hydroides elegans may be explained by disparities in their adult distribution in the field. The 
occurrence of the 2 barnacles is limited to particular tidal zones (mid to lower intertidal for Balanus amphitrite and subtidal for B. trigonus) (Harder et al. 2001, authors' unpubl data,). Since bacterial community composition in biofilms varies substantially among tidal zones, the differential response of barnacle larvae to biofilms with different bacterial community composition may allow the larvae finely evaluate substrata and hence precisely settle in appropriate tidal zones (Strathmann et al. 1981, Miron et al. 1999, Olivier et al. 2000, Qian et al. 2003). In contrast to the 2 barnacles, $H$. elegans occurs in a wider range of habitats and is often a pioneer colonizer of newly exposed surfaces. The larvae of $H$. elegans only appeared to settle in response to the bacterial density of the biofilms (Table 5). These results concur with those in a previous study that a low percentage $(<15 \%)$ of $H$. elegans larvae can readily settle on natural biofilms as young as 1 d old (Qian 1999), and that the intensity of larval settlement on biofilms of different ages was strongly correlated with the age and hence the bacterial density of the biofilms. This strategy may allow the widest spread of populations by having a small portion of larvae to rapidly colonize any open substrata. Since bacterial density is generally a function of biofilm age and thus a good indicator of substratum longevity, bacterial density dependent settlement may allow the majority of $H$. elegans larvae to settle on substrata that have been reasonably stable.

By coupling DNA fingerprinting techniques and larval settlement assays, our study exemplified the impact of environmental factors on the bacterial community composition of biofilms and the ability of marine invertebrate larvae to recognize biofilms with varying bacterial community composition. These results suggest that the composition and cell density of bacterial communities in biofilms may serve as signposts for larvae of the 2 barnacles and Hydroides elegans, respectively, to distinguish between habitats with different environmental conditions.

Acknowledgements. We thank L. Gosselin for useful suggestions on the manuscript. We also thank L. Soo, Y. K. Tam and M. Tsoi for technical assistance. This study was supported by a RGC grant (HKUST6281/03M) to P.-Y.Q.

\section{LITERATURE CITED}

Avelin M Sr, Rittschof D, Nagabhushanam R (1993) Bacterialbarnacle interaction: potential of using juncellins and antibiotics to alter structure of bacterial communities. J Chem Ecol 19:2155-2167

Bassam BJ, Caetano-Anolles G, Gresshoff PM (1991) Fast and sensitive silver staining of DNA in polyacrylamide gels. Anal Biochem 80:81-84

Beckmann M, Harder T, Qian PY (1999) Induction of larval attachment and metamorphosis in the serpulid polychaete Hydroides elegans by dissolved free amino acids: mode of action in laboratory assays. Mar Ecol Prog Ser 190: $167-178$

Bonar DB, Weiner RM, Colwell RR (1986) Microbial-invertebrate interactions and potential for biotechnology. Microb Ecol 12:101-110

Casamayor EO, Pedrós-Alió C, Muyzer G, Amann R (2002) Microheterogeneity in $16 \mathrm{~S}$ rDNA-defined bacterial populations from a stratified planktonic environment is related to temporal changes and to ecological adaptations. Appl Environ Microbiol 68:1706-1714

Egert M, Friedrich MW (2003) Formation of pseudo-terminal restriction fragments, a PCR-related bias affecting terminal restriction fragment length polymorphism analysis of microbial community structure. Appl Environ Microbiol 69:2555-2562

Eilers H, Pernthaler J, Glöckner FO, Amann R (2000) Culturability and in situ abundance of pelagic bacteria from the North Sea. Appl Environ Microbiol 66:3044-3051

Hadfield MG, Unabia CC, Smith CM, Michael TM (1994) Settlement preferences of the ubiquitous fouler Hydroides elegans. In: Thompson MF, Nagabhushanam R, Sarojini R, Fingerman $M$ (eds) Recent developments in biofouling control. Balkema, Rotterdam, p 65-74

Harder T, Thiyagarajan V, Qian PY (2001) Effect of cyprid age on the settlement of Balanus amphitrite Darwin in response to natural biofilms. Biofouling 17:211-219

Harder T, Lam C, Qian PY (2002) Induction of larval settlement in the polychaete Hydroides elegans by marine biofilms: an investigation of monospecific diatom films as settlement cues. Mar Ecol Prog Ser 229:105-112

Hoffmann T, Horz HP, Kemnitz D, Conrad R (2002) Diversity of the particulate methane monooxygenase gene in methanotrophic samples from different rice field soils in China and the Philippines. Syst Appl Microbiol 25: 267-274

Holmström C, Rittschof D, Kjelleberg S (1992) Inhibition of settlement of larvae of Balanus amphitrite and Ciona intestinalis by a surface-colonizing marine bacterium. Appl Environ Microbiol 58:2111-2115

Huang SH, Hadfield MG (2003) Composition and density of bacterial biofilms determine larval settlement of the polychaete Hydroides elegans. Mar Ecol Prog Ser 260: 161-172

Ishii K, Fukui M, Takii S (2000) Microbial succession during a compositing process as evaluated by denaturing gradient gel electrophoreses analysis. J Appl Microbiol 89:768-777

Keough MJ, Raimondi PT (1996) Responses of settling invertebrate larvae to bioorganic films: effects of large-scale variation in films. J Exp Mar Biol Ecol 207:59-78

Lau SCK, Qian PY (1997) Phlorotannins and related compounds as larval settlement inhibitors of a tube-building polychaete Hydroides elegans (Haswell). Mar Ecol Prog Ser 159:219-227

Lau SCK, Qian PY (2001) Larval settlement and metamorphosis in the serpulid polychaete Hydroides elegans (Haswell) in response to cues from bacterial films. Mar Biol 138: 321-328

Lau SCK, Mak KKW, Chen F, Qian PY (2002) Bioactivity of bacterial strains from marine biofilms in Hong Kong waters for the induction of larval settlement in the marine polychaete Hydroides elegans. Mar Ecol Prog Ser 226: 301-310

Le Tourneux F, Bourget E (1988) Importance of physical and biological settlement cues used at different scales by the larvae of Semibalanus balanoides. Mar Biol 97:57-66 
Maki JS, Rittschof D, Costlow JD, Mitchell R (1988) Inhibition of attachment of larval barnacles, Balanus amphitrite, by bacterial surface films. Mar Biol 97:199-206

Martin-Laurent F, Philippot L, Hallet S, Chaussod R, Germon JC, Soulas G, Catroux G (2001) DNA extraction from soils: old bias for new microbial diversity analysis methods. Appl Environ Microbiol 67:2354-2359

Miron G, Boudreau B, Bourget E (1999) Intertidal barnacle distribution: a case study using multiple working hypothesis. Mar Ecol Prog Ser 189:205-219

Morse ANC (1991) How do planktonic larvae know where to settle? Am Sci 79:154-167

Muyzer G (1998) Structure, function and dynamics of microbial communities: the molecular biological approach. In: Carvalho GR (ed) Advances in molecular ecology. IOS Press, Amsterdam, p 87-117

Nübel U, Engelen B, Felske A, Snaidr J, Wieshuber A, Amann R, Ludwig W, Backhaus H (1996) Sequence heterogeneities of genes encoding 16S rRNAs in Paenibacillus polymyxa detected by temperature gradient gel electrophoresis. J Bacteriol 178:5636-5643

O'Connor NJ, Richardson DL (1998) Attachment of barnacle (Balanus amphitrite Darwin) larvae: responses to bacterial films and extracellular materials. J Exp Mar Biol Ecol 226: 115-129

Olivier F, Tremblay R, Bourget E, Ritschoff D (2000) Barnacle settlement: field experiments on the influence of larval supply, tidal level, biofilm quality and age on Balanus amphitrite cyprids. Mar Ecol Prog Ser 199:185-204

Pearce JR, Scheibling RE (1991) Effect of macroalgae, microbial films, and conspecifics on the induction of metamorphosis of the green sea urchin, Strongylocentrotus droebachiensis (Müller). J Exp Mar Biol Ecol 147: $147-162$

Polz MF, Cavanaugh CM (1998) Bias in template-to-product

Editorial responsibility: Søren Rysgaard,

Silkeborg, Denmark ratios in multitemplate PCR. Appl Environ Microbiol 64: 3724-3730

Qian PY (1999) Larval settlement of polychaetes. Hydrobiologia 402:239-253

Qian PY, Thiyagarajan V, Lau SCK, Cheung SCK (2003) Relationship between bacterial community profile in biofilm and the attachment of acorn barnacle Balanus amphitrite Darwin. Aquat Microb Ecol 33:225-237

Rittschof D, Branscomb ES, Costlow JD (1984) Settlement and behaviour in relation to flow and surface in larval barnacles, Balanus amphitrite Darwin. J Exp Mar Biol Ecol 82: 131-146

Strathmann RR, Branscomb ES, Vedder K (1981) Fatal errors in set as a cost of dispersal and the influence of intertidal flora on set of barnacles. Oecologia 48:13-18

Thiyagarajan V, Harder T, Qian PY (2003) Combined effect of temperature and salinity on larval development and attachment of the subtidal barnacle Balanus trigonus Darwin. J Exp Mar Biol Ecol 287:223-236

Thomason JC, Hills JM, Clare AS, Neville A, Richardson M (1998) Hydrodynamic consequences of barnacle colonization. Hydrobiologia 375:1-21

Thorson G (1950) Reproductive and larval ecology of marine bottom invertebrates. Biol Rev 25:1-45

Unabia CRC, Hadfield MG (1999) Role of bacteria in larval settlement and metamorphosis of the polychaete Hydroides elegans. Mar Biol 133:55-64

Wieczorek SK, Todd CD (1998) Inhibition and facilitation of settlement of epifaunal marine invertebrate larvae by microbial biofilm cues. Biofouling 12:81-118

Zhou J, Bruns MA, Tiedje JM (1996) DNA recovery from soils of diverse composition. Appl Environ Microbiol 62:316-322

Zobell CD, Allen EC (1935) The significance of marine bacteria in the fouling of submerged surfaces. J Bacteriol 29(3): $239-251$

Submitted: July 29, 2004; Accepted: November 17, 2004

Proofs received from author: December 15, 2004 